Revista Eletrônica de Direito Processual - REDP.

Rio de Janeiro. Ano 10. Volume 17. Número 1. Janeiro a Junho de 2016

Periódico Semestral da Pós-Graduação Stricto Sensu em Direito Processual da UERJ

Patrono: José Carlos Barbosa Moreira. ISSN 1982-7636. pp. 92-111

http://www.e-publicacoes.uerj.br/index.php/redp/index

\title{
O INCIDENTE DE DESCONSIDERAÇÃO DA PERSONALIDADE JURÍDICA E O REDIRECIONAMENTO DA EXECUÇÃO FISCAL ${ }^{1}$
}

\section{THE LEGAL PERSONALITY DISREGARD INCIDENT AND THE IMPLEMENTATION OF FISCAL REDIRECTION}

\section{Elson Pereira de Oliveira Bastos}

Juiz de Direito. Professor de Direito Tributário da Escola da Magistratura do Estado de Rondônia - EMERON. Pósgraduado em Direito Tributário. emeron.jpr.elson@gmail.com

RESUMO: O novo CPC regulamentou, como modalidade de intervenção de terceiro, o denominado incidente de desconsideração da personalidade jurídica. Tendo em vista o reconhecido caráter de norma geral em matéria processual, como bem sinaliza o preceptivo do art. 15 do novo CPC, surge a relevância de se indagar sobre a aplicação das regras processuais do incidente em tela às hipóteses em que se autoriza o chamado redirecionamento da execução fiscal, tendo em vista as peculiaridades imanentes à configuração e ao modo de reconhecimento da responsabilidade tributária. Assim, é importante investigar a forma como a jurisprudência vinha autorizando o redirecionamento da execução fiscal e as implicações processuais produzidas pelo novel incidente de desconsideração da personalidade jurídica.

PALAVRAS-CHAVE: Redirecionamento da Execução Fiscal. Novo CPC. Incidente.

ABSTRACT: The new CPC (Civil Procedure Code) regulated as a third type of intervention, the incident called piercing the corporate veil. Given the general rule recognized character in procedural matters, as well signals the mandatory art. 15 from the new CPC, there is the importance of asking the application of the procedural rules of the

\footnotetext{
${ }^{1}$ Artigo recebido em 05/04/2016 e aprovado em 23/05/2016.
} 
Revista Eletrônica de Direito Processual - REDP.

Rio de Janeiro. Ano 10. Volume 17. Número 1. Janeiro a Junho de 2016

Periódico Semestral da Pós-Graduação Stricto Sensu em Direito Processual da UERJ

Patrono: José Carlos Barbosa Moreira. ISSN 1982-7636. pp. 92-111

http://www.e-publicacoes.uerj.br/index.php/redp/index

incident on screen to cases in which it authorizes the call redirection of tax enforcement, in

view of the inherent peculiarities of the definition and recognition of tax liability mode.

Therefore, it is important to investigate how the law was authorizing redirection of tax enforcement and procedural implications produced by the novel disregard incident of legal personality.

KEYWORDS: Redirection of Tax Enforcement. New CPC. Incident.

\section{INTRODUÇÃO}

O novo Código de Processo Civil inaugura uma nova fase do processo civil brasileiro. As inovações trazidas não se limitam às alterações sistemáticas ou topográficas dos temas processuais que constituem o seu objeto, mas propõem verdadeiras e radicais mudanças na forma de pensar e praticar o processo civil no Brasil. Ao lado das preocupações com o devido processo legal formal, ou de garantias ritualísticas, há inegável avanço em temas de orientação conteudística, sob as coordenadas do devido processo legal de matriz substancial, merecendo destaque, apenas a título de exemplo, as disposições sobre a não surpresa, o poder de influência das partes e a paridade de armas.

A partir da análise da legislação e levando-se em consideração a jurisprudência forjada antes do novo Código de Processo Civil, propõe-se investigar, com fundamento na doutrina processual e constitucional mais consentânea com o Estado Democrático de Direito, a aplicabilidade do novo incidente de desconsideração da personalidade jurídica no campo processual tributário, precisamente em relação ao que se convencionou chamar de redirecionamento da execução fiscal. Perfilharemos este caminho partindo do panorama atual do redirecionamento da execução fiscal. Em seguida nos debruçaremos sobre a compreensão do princípio do contraditório em seu viés material ou substancial, com realce ao poder de influência. Adiante analisaremos a importância do poder de conformação do legislador para o delineamento do princípio do contraditório e, por seguinte, da possibilidade e limites de sua relativização. Avançaremos posicionando o regramento do incidente de desconsideração da personalidade jurídica no novo Código de Processo Civil e, empós, a par dos ensinamentos mais atuais em relação ao princípio do contraditório, nos concentraremos 
Revista Eletrônica de Direito Processual - REDP.

Rio de Janeiro. Ano 10. Volume 17. Número 1. Janeiro a Junho de 2016

Periódico Semestral da Pós-Graduação Stricto Sensu em Direito Processual da UERJ

Patrono: José Carlos Barbosa Moreira. ISSN 1982-7636. pp. 92-111 http://www.e-publicacoes.uerj.br/index.php/redp/index

na análise da aplicabilidade do procedimento do incidente de desconsideração da personalidade jurídica às hipóteses de redirecionamento da execução fisscal. Por fim, focaremos a atenção na necessidade de tutela provisória de urgência (ou medida equivalente), de natureza cautelar, para se alcançar o desiderato de constranger o patrimônio do sócio com vistas a garantir o pleno êxito ou efetividade do processo de execução físcal.

Nesse caminhar, pretende-se demonstrar que o procedimento do novo incidente de intervenção de terceiro previsto no atual CPC deve ser aplicado ao redirecionamento da execução fiscal como exigência de realização plena do contraditório efetivo.

\section{SISTEMÁTICA ATUAL DO REDIRECIONAMENTO DA EXECUÇÃO} FISCAL

O redirecionamento da execução fiscal é a forma como os tribunais têm lidado com o tema da desconsideração da personalidade jurídica no terreno fiscal. Por meio dessa práxis pretoriana é que o fisco consegue alcançar, no bojo da execução fiscal, o patrimônio do sócio da pessoa jurídica contribuinte. As hipóteses mais comuns de redirecionamento da execução fiscal tem guarida no art. 135, III, do Código Tributário Nacional ${ }^{2}$.

A despeito da crítica de parcela da doutrina que denuncia a existência de celeuma entre os institutos da responsabilidade tributária (responsabilidade pessoal) e o da desconsideração da personalidade jurídica ${ }^{2}$, fato é que os Tribunais pátrios veem no art. 135, III, do Código Tributário Nacional reais hipóteses de desconsideração da personalidade jurídica a viabilizar o redirecionamento do executivo fiscal contra o sócio-gerente ou administrador, sendo a situação mais corriqueira a da extinção irregular da pessoa jurídica, entendida como caso de fraude à lei.

O Superior Tribunal de Justiça, por todos, tem iterativa jurisprudência na linha de entendimento aqui mencionada ${ }^{3}$.

\footnotetext{
${ }^{2}$ Art. 135. São pessoalmente responsáveis pelos créditos correspondentes a obrigações tributárias resultantes de atos praticados com excesso de poderes ou infração de lei, contrato social ou estatutos: I - as pessoas referidas no artigo anterior; II - os mandatários, prepostos e empregados; III - os diretores, gerentes ou representantes de pessoas jurídicas de direito privado.

3 “(...) 1. A desconsideração da personalidade jurídica, com a consequente invasão no patrimônio dos sócios para fins de satisfação de débitos da empresa, é medida de caráter excepcional, sendo apenas admitida nas hipóteses expressamente previstas no art. 135 do CTN ou nos casos de dissolução irregular da empresa, que nada mais é que infração à lei...” (BRASIL. Superior Tribunal de Justiça, AgRg no REsp 1534236/PE, Rel. Min. Humberto Martins, Segunda Turma, j. 18.08.2015, DJe 25/08/2015. Disponível em
} 
Revista Eletrônica de Direito Processual - REDP.

Rio de Janeiro. Ano 10. Volume 17. Número 1. Janeiro a Junho de 2016

Periódico Semestral da Pós-Graduação Stricto Sensu em Direito Processual da UERJ

Patrono: José Carlos Barbosa Moreira. ISSN 1982-7636. pp. 92-111 http://www.e-publicacoes.uerj.br/index.php/redp/index

É expressivo, nesse mesmo sentido, o que anuncia o verbete n. 435 da Súmula do

Superior Tribunal de Justiça: "Presume-se dissolvida irregularmente a empresa que deixar de funcionar no seu domicílio fiscal, sem comunicação aos órgãos competentes, legitimando o redirecionamento da execução fiscal para o sócio-gerente."

Configurada nos autos da execução fiscal alguma das hipóteses descritas no art. 135, III, do Código Tributário Nacional, o chamado redirecionamento da execução fiscal é medida apta a ser deflagrada e, uma vez deferida, ensejará a prática de atos de constrição patrimonial em relação ao acervo patrimonial do sócio responsável.

A decisão sobre a configuração ou não da hipótese de redirecionamento fica adstrita ao alegado e provado pelo físco e se dá em juízo de verossimilhança ou probabilidade. De regra não há prévia intimação (ou citação) do sócio para o exercício do contraditório a tempo de impedir o deferimento do redirecionamento do executivo tributário e a realização de medidas constritivas contra o seu patrimônio. O contraditório a ser exercido pelo sócio, no mais das vezes, fica diferido e será instrumentalizado por meio dos embargos à execução ${ }^{5}$ ou, excepcionalmente, pela via da exceção de pré-executividade.

Portanto, consoante é a prática jurisprudencial, a atual sistemática processual em que se autoriza o redirecionamento da execução fiscal, não se preocupa com o contraditório prévio ao ingresso do terceiro (sócio) no processo de execução fiscal, o qual somente poderá influir sobre esta decisão em momento futuro, quando já sob os efeitos jurídicos decorrentes do ato judicial deferitório do redirecionamento (constrição patrimonial).

\footnotetext{
http://www.stj.jus.br/SCON/jurisprudencia/toc.jsp?tipo_visualizacao=null\&livre=tribut\%E1rio+e+redirecion amento+e+poderes + de + gest\%E3o\&b=ACOR\&thesaurus=JURIDICO. Acesso em 03 de abril de 2016).

4 BRASIL. Superior Tribunal de Justiça. Súmula 435. Disponível em http://www.stj.jus.br/SCON/pesquisar.jsp?acao $=$ pesquisar\&novaConsulta $=$ true $\& \mathrm{i}=1 \&$ data $=\&$ livre $=435 \&$ op Ajuda $=$ SIM\&tipo_visualizacao $=$ null\&thesaurus $=$ null $\& \mathrm{p}=$ null\&operador $=\mathrm{e} \&$ processo $=\& l i v r e M i n i s t r o=\&$ rela tor $=\&$ data_inicial $=\& d a t a \_f i n a l=\&$ tipo $\_$data $=$DTDE $\&$ livreOrgaoJulgador $=\&$ orgao $=\&$ ementa $=\&$ ref $=\&$ siglaju $\mathrm{d}=$ \&numero_leg=\&tipo1 $=\&$ numero_art $1=\&$ tipo $2=\&$ numero_art $2=\&$ tipo $3=\&$ numero_art3 $=\&$ nota $=\& \mathrm{~b}=\mathrm{SUM}$ U. Acesso em 03 de abril de 2016.

5 “(...) 1. Refoge à competência do Superior Tribunal de Justiça apreciar suposta ofensa a dispositivos constitucionais, ainda que para fins de prequestionamento, sob pena de invasão da competência do Supremo Tribunal Federal. 2. A verificação da presença dos requisitos para a aplicação da disregard doctrine previstos no art. 50 do Código Civil, por constituir matéria fática, é vedada pelo enunciado n. 7 da Súmula do STJ. Precedente. 3. Segundo a jurisprudência do STJ, a desconsideração da personalidade jurídica, como incidente processual, pode ser decretada sem a prévia citação dos sócios atingidos, aos quais se garante o exercício postergado ou diferido do contraditório e da ampla defesa. Precedentes de ambas as Turmas que integram a Segunda Seção do STJ. 4. Se o agravante não traz argumentos aptos a infirmar os fundamentos da decisão agravada, deve-se negar provimento ao agravo regimental. Precedente. 5. Agravo regimental a que se nega provimento." (AgRg no REsp 1459784/MS, Rel. Min. Marco Aurélio Bellizze, Terceira Turma, julgado em 04/08/205, DJe 14/08/2015).
} 
Revista Eletrônica de Direito Processual - REDP.

Rio de Janeiro. Ano 10. Volume 17. Número 1. Janeiro a Junho de 2016

Periódico Semestral da Pós-Graduação Stricto Sensu em Direito Processual da UERJ

Patrono: José Carlos Barbosa Moreira. ISSN 1982-7636. pp. 92-111 http://www.e-publicacoes.uerj.br/index.php/redp/index

\section{CONTRADITÓRIO SUBSTANCIAL - PODER DE INFLUÊNCIA}

Dimanam do princípio do contraditório duas facetas de garantias ${ }^{6}$, uma ligada à dimensão formal e a outra, à dimensão substancial do princípio. A dimensão formal é marcada pela garantia de participação (audiência, comunicação, ciência), ao passo que a dimensão substancial é revelada pela garantia de influência na decisão ${ }^{7}$.

Trata-se de desdobramento da cláusula do devido processo legal (due process of law) em sua extensão formal (procedural due process) e substancial (substantive due process).

A dimensão substancial do princípio do contraditório não se contenta com a simples ouvida ou participação da parte no processo, indo além para exigir que essa participação seja em condições de poder influenciar a decisão do órgão jurisdicional.

Em abordagem de direito comparado, Gilmar Ferreira Mendes expõe relevantes fundamentos da doutrina alemã acerta do tema: "Não é outra a avaliação do tema no direito constitucional comparado. Apreciando o chamado 'Anspruch auf rechtliches Gehör' ('pretensão à tutela jurídica') no direito alemão, assinala a Corte Constitucional que essa pretensão envolve não só o direito de manifestação e o direito de informação sobre o objeto do processo, mas também o direito de ver os seus argumentos contemplados pelo órgão incumbido de julgar". . E prossegue: "Daí afirmar-se, correntemente, que a pretensão à tutela jurídica, que corresponde exatamente à garantia consagrada no art. $5^{\circ}, L V$, da Constituição, contém os seguintes direitos: - direito de informação ('Recht auf Information'), que obriga o órgão julgador a informar à parte contrária dos atos praticados no processo e sobre os elementos dele constantes; - direito de manifestação ('Recht auf Äusserung'), que assegura ao defendente a possibilidade de manifestar-se oralmente ou por escrito sobre os elementos fáticos e jurídicos constantes do processo; - direito de ver seus argumentos considerados ('Recht auf Berücksichtigung'), que exige do julgador capacidade, apreensão

\footnotetext{
6 As expressões "direitos fundamentais" e "garantias fundamentais" são utilizadas indistintamente neste trabalho, sem preocupação classificatória.

${ }^{7}$ DIDIER JR., Fredie. Curso de Direito Processual Civil: introdução ao direito processual civil, parte geral e processo de conhecimento. $17^{\mathrm{a}}$ ed. Salvador. Jus Podivm, 2015, p. 78.

${ }^{8}$ MENDES, Gilmar Ferreira. Direitos Fundamentais e Controle de Constitucionalidade: estudos de direito constitucional. $4^{\text {a }}$ ed. São Paulo. Saraiva, 2012, p. 279.
} 
Revista Eletrônica de Direito Processual - REDP.

Rio de Janeiro. Ano 10. Volume 17. Número 1. Janeiro a Junho de 2016

Periódico Semestral da Pós-Graduação Stricto Sensu em Direito Processual da UERJ

Patrono: José Carlos Barbosa Moreira. ISSN 1982-7636. pp. 92-111 http://www.e-publicacoes.uerj.br/index.php/redp/index

e isenção de ânimo ('Aufnahmefähigkeit und Aufnahmebereitschaft') para contemplar as razões apresentadas." 9

Quanto a esse último aspecto, arremata Gilmar Ferreira Mendes que: "Sobre o direito de ver os seus argumentos contemplados pelo órgão julgador, que corresponde, obviamente, ao dever do juiz de a eles conferir atenção, pode-se afirmar que envolve não só o dever de tomar conhecimento, como também o de considerar, séria e detidamente, as razões apresentadas. É da obrigação de considerar as razões apresentadas que também deriva o dever de fundamentar as decisões (CF, art. 93, IX)."10.

No Mandado de Segurança n. 26849-AgR, o Ministro Luiz Fux também asseverou a dimensão substancial do contraditório, realçando, com escólio na doutrina brasileira e italiana, a importância de se preservar o poder de influência. Consta do seu voto, nesse particular, a seguinte digressão: "Na realidade, a garantia do contraditório reclama que, uma vez verificada que uma dada ação estatal possa vulnerar objetivamente a esfera jurídica do cidadão, seja salvaguardada a prerrogativa de pronunciar-se previamente acerca de todas as questões fáticas e jurídicas debatidas no processo com vistas a subsidiar uma decisão amadurecida da controvérsia, inclusive acerca daquelas matérias que o magistrado pode ex officio conhecer." 11

\footnotetext{
${ }^{9}$ MENDES, Gilmar Ferreira. Direitos Fundamentais e Controle de Constitucionalidade: estudos de direito constitucional. $4^{\mathrm{a}}$ ed. São Paulo. Saraiva, 2012, p. 279-280.

${ }^{10}$ MENDES, Gilmar Ferreira. Direitos Fundamentais e Controle de Constitucionalidade: estudos de direito constitucional. $4^{a}$ ed. São Paulo. Saraiva, 2012, p. 280.

11 "Com efeito, a hodierna concepção de contraditório refere-se ao direito de participação e de influência nos rumos do processo (CABRAL, Antônio do Passo. II principio del contradditorio come diritto d'influenza e dovere di dibattito. Rivista di Diritto Processuale. Padova: Cedam, 2005; OLIVEIRA, Carlos Alberto. O juiz e o princípio do contraditório. Revista do advogado, $\mathrm{n}^{\circ}$ 40, p. 35-38, jul. 1993), superando, assim, a visão que a restringia à simples bilateralidade de instância, dirigindo-se apenas às partes do processo. Na realidade, a garantia do contraditório reclama que, uma vez verificada que uma dada ação estatal possa vulnerar objetivamente a esfera jurídica do cidadão, seja salvaguardada a prerrogativa de pronunciar-se previamente acerca de todas as questões fáticas e jurídicas debatidas no processo com vistas a subsidiar uma decisão amadurecida da controvérsia, inclusive acerca daquelas matérias que o magistrado pode ex officio conhecer (g.n.) (COMOGLIO, Paolo. La garantizia dell' azione ed il processo civile. Padova: Cedam, 1970, p. 145-146). Essa exigência encontra-se intimamente atrelada à ideia de contenção do arbítrio estatal, corolário do constitucionalismo, de vez que interdita comportamentos e decisões dos órgãos e agentes públicos lesivos ao patrimônio jurídico do cidadão. Tal imperativo se justifica, pelo menos, por duas razões: em primeiro lugar, por razões de segurança jurídica e de boa-fé objetiva, na medida em que o indivíduo não será surpreendido com uma decisão estatal que lhe seja desfavorável sem seu prévio conhecimento; e, em segundo lugar, a sua prévia manifestação pode fornecer novos argumentos que irão subsidiar o - e influir no futuro pronunciamento estatal (jurisdicional ou administrativo), tornando a decisão mais consistente e, por conseguinte, legítima." (BRASIL. Supremo Tribunal Federal. MS 26849 AgR, Rel. Min. Luiz Fux, Tribunal Pleno, j. em 10/04/2014, DJe-096. Disponível em
} http://www.stf.jus.br/portal/jurisprudencia/visualizarEmenta.asp?s1=000235038\&base=baseAcordaos. Acesso em 04 de abril de 2016). 
Revista Eletrônica de Direito Processual - REDP.

Rio de Janeiro. Ano 10. Volume 17. Número 1. Janeiro a Junho de 2016

Periódico Semestral da Pós-Graduação Stricto Sensu em Direito Processual da UERJ

Patrono: José Carlos Barbosa Moreira. ISSN 1982-7636. pp. 92-111 http://www.e-publicacoes.uerj.br/index.php/redp/index

Carlos Alberto Alvaro de Oliveira bem sintetiza a visão moderna em torno do contraditório: "Na visão atual, o direito fundamental do contraditório situa-se para além da simples informação e possibilidade de reação, conceituando-se de forma mais ampla na outorga de poderes para que as partes participem no desenvolvimento e no resultado do processo, da forma mais paritária possivel, influenciando de modo ativo e efetivo a formação dos pronunciamentos jurisdicionais. " 12

Em sintonia com essa orientação material do contraditório, o novo CPC tem como um de seus pontos de estofo o reforço à participação das partes no processo e a viabilidade da prática argumentativa como forma privilegiada de orientar as decisões judiciais ${ }^{13}$.

O princípio da cooperação (art. $6^{\circ}, \mathrm{CPC}$ ) e a regra da proibição de decisão surpresa (art. 10, CPC) são sintomáticos dessa novel principiologia.

\section{CONTRADITÓRIO EFETIVO E A LIBERDADE DE CONFORMAÇÃO} DO LEGISLADOR

O princípio do contraditório tem amplo espectro sujeito à liberdade de conformação do legislador ${ }^{14}$, embora seu âmbito de proteção não seja estritamente normativo.

Por essa razão, as limitações a esse direito fundamental são compreendidas no bojo da própria regulação ou conformação legislativa, deslocando o debate sobre as restrições a essa garantia fundamental para os limites da liberdade da atuação do poder legislativo ${ }^{15}$.

\footnotetext{
${ }^{12}$ OLIVEIRA, Carlos Alberto Alvaro de. Comentário ao art. $5^{\circ}$, LV. In: CANOTILHO, J.J. Gomes; MENDES, Gilmar F.; SARLET, Ingo W.; STRECK, Lenio L. (Coords.). Comentários à Constituição do Brasil. $1^{\text {a }}$ ed. São Paulo. Saraiva, 2014.

13 "O juiz - ou qualquer outra autoridade competente para aplicar o direito - deve estar aberto ao diálogo, sob pena de não se legitimar democraticamente, uma vez que o sentido a ser atribuído a um determinado caso concreto, embora não esteja encapsulado no texto normativo, tampouco poderá ser atribuído discricionariamente.” In: CARNEIRO, Wálber.

14 "Não raro, a definição do âmbito de proteção de certo direito depende de uma interpretação sistemática, abrangente de outros direitos e disposições constitucionais. Muitas vezes, a definição do âmbito de proteção somente há de ser obtida em confronto com eventual restrição a esse direito. [...] Não raro, o constituinte confere ao legislador ordinário um amplo poder de conformação, permitindo que a lei concretize ou densifique determinada faculdade fundamental." In: MENDES, Gilmar Ferreira. Direitos Fundamentais e Controle de Constitucionalidade, p. 35-35.

${ }^{15}$ MENDES, Gilmar Ferreira. Direitos Fundamentais e Controle de Constitucionalidade: estudos de direito constitucional. $4^{\mathrm{a}}$ ed. São Paulo. Saraiva, 2012, p. 38.
} 
Revista Eletrônica de Direito Processual - REDP.

Rio de Janeiro. Ano 10. Volume 17. Número 1. Janeiro a Junho de 2016

Periódico Semestral da Pós-Graduação Stricto Sensu em Direito Processual da UERJ

Patrono: José Carlos Barbosa Moreira. ISSN 1982-7636. pp. 92-111 http://www.e-publicacoes.uerj.br/index.php/redp/index

É certo que o legislador não tem livre disposição sobre a matéria. O seu poder de conformação não passa ao largo de considerar os demais direitos e garantias fundamentais, encarando-se a Constituição como uma unidade e sistema, além de preservar a tradição ${ }^{16}$.

$\mathrm{O}$ direito ao contraditório está ligado diretamente à ideia de processo justo ${ }^{17}$. Guilherme Marinoni e Daniel Mitidiero ${ }^{18}$ aludem que o contraditório já foi identificado como simples bilateralidade da instância, mas que a doutrina moderna tem identificado nele a ideia de cabal participação como núcleo-duro, traduzido no direito de influência.

Se o âmbito de proteção da garantia do contraditório é formatado à luz dessa perspectiva substantiva, que compreenderia, portanto, o seu núcleo intangível, o processo de conformação legislativa não pode olvidar a salvaguarda também dessa faceta da proteção efetiva, sob pena de confrontar a Constituição.

Importante observar, como aliás já se mencionou, que o direito ao contraditório está imbricado a outros direitos de igual dignidade constitucional e que compreendem a noção de processo justo ${ }^{19}$ ou, ainda, de proteção judicial efetiva ${ }^{20}$. Disso resulta a necessidade de, muitas vezes, "harmonizá-lo com os seus demais elementos estruturantes, em especial com o direito à tutela adequada e efetiva dos direitos" 21 .

\footnotetext{
16 "Há uma legitimidade política do legislador que lhe permite, no 'espaço estrutural-constitucional', fazer opções.” In: STRECK, Lenio. Jurisdição Constitucional e Decisão Jurídica, $3^{\mathrm{a}}$ ed. Reformulada da obra Jurisdição Constitucional e Hermenêutica. São Paulo. Revista dos Tribunais, 2013, p. 117.

17 "Tamanha a sua importância que o próprio conceito de processo no Estado Constitucional está construído sob sua base." In: SARLET, Ingo Wolfgang; MARINONI, Luiz Guilherme; MITIDIERO, Daniel. Curso de Direito Constitucional. São Paulo. Revista dos Tribunais, 2012, p. 646-647.

18 SARLET, Ingo Wolfgang; MARINONI, Luiz Guilherme; MITIDIERO, Daniel. Curso de Direito Constitucional. São Paulo. Revista dos Tribunais, 2012, p. 647-648.

${ }^{19}$ Discorrendo sobre o âmbito de proteção do direito fundamental à tutela jurisdicional, Guilherme Marinoni e Daniel Mitidiero aludem que: "O direito à tutela jurisdicional deve ser analisado no mínimo sob três perspectivas: (i) do acesso à justiça; (ii) da adequação da tutela; e (iii) da efetividade da tutela. (...) $\mathrm{O}$ acesso à justiça diz respeito à amplitude da prestação da tutela jurisdicional, ao momento em que pode ser proposta a ação e ao custo financeiro do processo. (...) A tutela jurisdicional tem de ser adequada para tutela dos direitos. $\mathrm{O}$ processo tem de ser capaz de promover a realização do direito material. O meio tem de ser idôneo à promoção do fim. (...) A efetividade da tutela jurisdicional diz respeito ao resultado do processo. Mais precisamente, concerne à necessidade de o resultado da demanda espelhar o mais possível o direito material, propiciando-se às partes sempre tutela específica - ou tutela pelo resultado prático equivalente - em detrimento da tutela pelo equivalente monetário." In: SARLET, Ingo Wolfgang; MARINONI, Luiz Guilherme; MITIDIERO, Daniel. Curso de Direito Constitucional. São Paulo. Revista dos Tribunais, 2012, p. 628-637.

20 "A ordem constitucional brasileiro assegura, de forma expressa, desde a Constituição de 1946 (art. 141, § $\left.4^{\circ}\right)$, que a lei não excluirá da apreciação do Poder Judiciário lesão ou ameaça a direito (CF/88, art. $\left.5^{\circ}, \mathrm{XXXV}\right)$. Tem-se (...) a consagração da tutela judicial efetiva, que garante a proteção judicial contra lesão ou ameaça a direito." In: MENDES, Gilmar Ferreira. Direitos Fundamentais e Controle de Constitucionalidade, p. 219.

${ }^{21}$ SARLET, Ingo Wolfgang; MARINONI, Luiz Guilherme; MITIDIERO, Daniel. Curso de Direito Constitucional. São Paulo. Revista dos Tribunais, 2012, p. 650.
} 
Revista Eletrônica de Direito Processual - REDP.

Rio de Janeiro. Ano 10. Volume 17. Número 1. Janeiro a Junho de 2016

Periódico Semestral da Pós-Graduação Stricto Sensu em Direito Processual da UERJ

Patrono: José Carlos Barbosa Moreira. ISSN 1982-7636. pp. 92-111 http://www.e-publicacoes.uerj.br/index.php/redp/index

Nessa dicção, o legislador, no seu mister de conformação dos direitos fundamentais, consagrou de forma expressa regra de compatibilização entre o direito fundamental ao contraditório efetivo, por um lado, e o direito à efetividade da tutela jurisdicional (corolário do princípio da proteção judicial efetiva - art. $5^{\circ}, \mathrm{XXXV}, \mathrm{CF}$ ), por outro, prevendo textualmente no art. $9^{\circ}$, parágrafo único ${ }^{22}$, do atual Código de Processo Civil as hipóteses em que se permite o diferimento do contraditório ${ }^{23}$.

Mas ainda há outras hipóteses legais de conformação do contraditório em que se permite o seu diferimento, merecendo destaque, no espaço do processo judicial tributário, as disposições alusivas às medidas cautelares fiscais previstas na Lei 8.397/92.

Havendo primazia do legislador ${ }^{24}$ no tratamento do âmbito de proteção dos direitos fundamentais, fruto do seu poder de conformação, impõe ao órgão jurisdicional a observância do direito positivo ${ }^{25}$, somente se permitindo o afastamento da lei quando, no caso concreto, frente a circunstâncias específicas, revelar-se inconstitucional a aplicação do seu preceito normativo. Nessa hipótese haverá sopensamento in concreto dos direitos fundamentais em jogo $^{26}$, cuja solução não poderá prescindir da necessária exposição dos fundamentos utilizados para alcançá-la (art. 489, § $2^{\circ}$, do CPC/15).

\footnotetext{
${ }^{22}$ Art. $9^{\circ}$. Não se proferirá decisão contra uma das partes sem que ela seja previamente ouvida. Parágrafo único. O disposto no caput não se aplica: I - à tutela provisória de urgência; II - às hipóteses de tutela da evidência previstas no art. 311, incisos II e III; III - à decisão prevista no art. 701.

${ }_{23}$ "Em geral, no processo /.../ o contraditório é prévio. Audiatur et altera pars. Primeiro o juiz ouve ambas as partes para tão somente depois decidir. Pode ocorrer, contudo, de o órgão jurisdicional ter que decidir de forma provisória determinada questão ao longo do processo antes de ouvir uma das partes (inaudita altera parte). (...) O contraditório aí fica postergado - diferido - para depois da concessão da tutela jurisdicional. A restrição ao contraditório ocorre em função da necessidade de adequação e efetividade da tutela jurisdicional". In: SARLET, Ingo Wolfgang; MARINONI, Luiz Guilherme; MITIDIERO, Daniel. Curso de Direito Constitucional. São Paulo. Revista dos Tribunais, 2012, p. 650.

24 “Ao Legislativo toca, precipuamente, a criação do direito positivo". In: BARROSO, Luís Roberto. Direito Constitucional Contemporâneo, p. 417.

${ }^{25}$ Sobre a interpretação constitucional e falando do princípio da divisão de poderes e o correlato princípio da conformidade funcional, adverte Ingo Sarlet: "De acordo com Konrad Hesse, tal principio de interpretação constitucional vale especialmente para as relações entre o legislador e a Jurisdição Constitucional, de modo que a esta incumbe apenas uma função de controle da legislação não podendo chegar ao ponto de subtrair ou mesmo limitar a liberdade de conformação do legislador para além dos limites impostos pela Constituição." In: SARLET, Ingo Wolfgang; MARINONI, Luiz Guilherme; MITIDIERO, Daniel. Curso de Direito Constitucional. São Paulo. Revista dos Tribunais, 2012, p. 219.

26 "Recorde-se que, na seara judicial, há hipóteses em que o magistrado avalia a constitucionalidade da ponderação feita por outros órgãos, e outras em que ele é instado a realizar por si o sopesamento dos interesses em confronto. No primeiro caso /.../ ele deve manter uma postura de deferência diante das ponderações realizadas, respeitando a margem de escolha dos demais poderes. (...) Já no segundo caso, cabe ao Judiciário avaliar, à luz das circunstâncias do caso, quais são as alternativas possíveis de solução para o problema constitucional com que se defronta, testando-as em exercício intelectual, para verificar qual delas melhor se amolda às exigências do princípio da proporcionalidade...". In: SOUZA NETO, Cláudio Pereira e SARMENTO, Daniel. Direito Constitucional - Teoria, história e métodos de trabalho, p. 520.
} 
Revista Eletrônica de Direito Processual - REDP.

Rio de Janeiro. Ano 10. Volume 17. Número 1. Janeiro a Junho de 2016

Periódico Semestral da Pós-Graduação Stricto Sensu em Direito Processual da UERJ

Patrono: José Carlos Barbosa Moreira. ISSN 1982-7636. pp. 92-111 http://www.e-publicacoes.uerj.br/index.php/redp/index

Sendo o poder de influir imanente ao princípio do contraditório, o qual se subordina a primacial conformação do legislador, somente nas estritas balizas da atuação legislativa é que seria possível a imposição de alguma limitação a essa faceta deontológica do princípio. As hipóteses de relativização do contraditório, portanto, seriam típicas (ex lege), razão pela qual apenas nos casos previstos em lei haveria a possibilidade de se permitir o ingresso na esfera de direitos patrimoniais de outrem sem o prévio contraditório.

Sem prejuízo do quanto se disse, é claro que sempre será possível o controle de constitucionalidade sob a perspectiva da proporcionalidade in concreto $^{27}$, uma vez que, como adverte Gilmar Ferreira $\mathrm{Mendes}^{28}$, nem sempre a solução ou fórmula legislativa contém uma valoração definitiva de todos os aspectos e circunstâncias que compõem cada caso ou hipótese de aplicação.

\section{O NOVO MODELO - O INCIDENTE DE DESCONSIDERAÇÃO DA PERSONALIDADE JURÍdICA PREVISTO NO NOVO CÓDIGO DE PROCESSO CIVIL}

O incidente de desconsideração da personalidade jurídica é concebido pelo novo Código de Processo Civil como modalidade de intervenção de terceiro, encontrando regramento nos arts. 133 a 137 do referido Código.

Na disciplina desse incidente processual, o contraditório é instalado de forma regular, isto é, tem configuração prévia à tomada da decisão.

Consoante dispõe o art. 135 do novo Código de Processo Civil ${ }^{29}$, instaurado o incidente, o sócio será citado para manifestar-se e requerer as provas cabíveis no prazo de quinze dias. Somente após a oportunidade de ouvida do sócio ou concluída a instrução, quando necessária, é que o incidente será decidido (art. 136, CPC) $)^{30}$.

Frente a esse novo regramento legal, garante-se o contraditório efetivo ou substancial àquele que terá o seu patrimônio alcançado por força da desconsideração da personalidade

\footnotetext{
${ }^{27}$ Teoria do duplo controle de proporcionalidade. Essa temática é explorada de forma percuciente pelo Ministro Sepúlveda Pertence em voto na ADI 223.

${ }^{28}$ MENDES, Gilmar Ferreira. Direitos Fundamentais e Controle de Constitucionalidade: estudos de direito constitucional. $4^{\text {a }}$ ed. São Paulo. Saraiva, 2012, p. 80.

${ }^{29}$ Art. 135. Instaurado o incidente, o sócio ou a pessoa jurídica será citado para manifestar-se e requerer as provas cabíveis no prazo de 15 (quinze) dias.

${ }^{30}$ Art. 136. Concluída a instrução, se necessária, o incidente será resolvido por decisão interlocutória.
} 
Revista Eletrônica de Direito Processual - REDP.

Rio de Janeiro. Ano 10. Volume 17. Número 1. Janeiro a Junho de 2016

Periódico Semestral da Pós-Graduação Stricto Sensu em Direito Processual da UERJ

Patrono: José Carlos Barbosa Moreira. ISSN 1982-7636. pp. 92-111

http://www.e-publicacoes.uerj.br/index.php/redp/index

jurídica. Quem esteja nessa posição, assim, terá a oportunidade de influir previamente a tomada da decisão judicial que poderá afetar a sua esfera de direitos, ou seja, antes da decisão do juízo ou tribunal acerca da existência dos requisitos legais autorizadores da desconsideração da personalidade jurídica e consequente invasão na órbita dos seus direitos patrimoniais.

Com isso, não apenas é garantido o direito a prévia manifestação, mas se potencializa o poder de influir na formação da convicção do juiz acerca da inviabilidade do pleito formulado pelo credor, de sorte que as regras disciplinadoras do incidente estão em perfeita sintonia com a Constituição no que toca à tutela do direito fundamental ao contraditório.

\section{DA APLICABILIDADE DAS REGRAS DO INCINCIDENTE DE DESCONSIDERAÇÃO DA PERSONALIDADE JURÍDICA ÀS HIPÓTEES DE REDIRECIONAMENTO DA EXECUÇÃO FISCAL}

Os preceitos legais do incidente de desconsideração da personalidade jurídica previsto no novo Código de Processo Civil devem ser aplicados às hipóteses de redirecionamento da execução fiscal.

Essa aplicação se impõe de forma direta, independentemente do recurso à complementaridade supletiva ou subsidiária (art. 15, CPC). Isso porque é o próprio Código de Processo Civil que regula as questões processuais afetas às demandas de teor tributário, sem se olvidar, evidentemente, a legislação especial nessa matéria, da qual é exemplo a Lei das Execuções Fiscais (Lei 6.830/80).

De qualquer maneira, é importante considerar que inexiste regramento específico para a desconsideração da personalidade jurídica em ação de conteúdo tributário ou mesmo para o redirecionamento da execução fiscal. Assim, também por esse ângulo, soa inexorável a aplicação das disposições do novo Código de Processo Civil, também nessa parte, ao âmbito das execuções fiscais, pois não há norma especial a prevalecer sobre a geral.

Mas a imperiosidade de observância do procedimento do incidente da desconsideração da personalidade jurídica em sede de execução fiscal também é extraída da leitura principiológica do novo Código de Processo Civil, tendo em vista o que se falou sobre o contraditório efetivo ou substancial. 
Revista Eletrônica de Direito Processual - REDP.

Rio de Janeiro. Ano 10. Volume 17. Número 1. Janeiro a Junho de 2016

Periódico Semestral da Pós-Graduação Stricto Sensu em Direito Processual da UERJ

Patrono: José Carlos Barbosa Moreira. ISSN 1982-7636. pp. 92-111 http://www.e-publicacoes.uerj.br/index.php/redp/index

Sendo o poder de influência uma face irrecusável do contraditório, que homenageia o próprio princípio democrático na perspectiva da legitimação argumentativa das decisões judiciais, não se pode desprezar as regras procedimentais da aludida intervenção de terceiro, sob pena de malferir a própria Constituição Federal no que assegura o direito fundamental ao contraditório, naquilo que se compreende por contraditório material ou efetivo.

Poder-se-ia objetar que o redirecionamento da execução fiscal importa no arrastamento do sócio para o polo passivo da execução fiscal de forma anômala ou atípica, o que estaria de acordo com as normas tributárias de conteúdo material relacionadas à tipificação das hipóteses de responsabilidade tributária, não sendo o sócio verdadeiramente um terceiro, no sentido técnico-processual da expressão.

Assim, em consonância com as regras concernentes aos casos de responsabilidade tributária, poderia o fisco, a qualquer tempo, desde que não ultimada a prescrição do crédito tributário em relação ao sócio $^{31}$, postular a inclusão do responsável no polo passivo da execução fiscal, aplicando-se o regramento procedimental próprio da ação de execução fiscal, o que implicaria a citação do sócio para garantir o juízo a fim de viabilizar a propositura dos embargos à execução, à semelhança do que se dá em relação ao devedor originário.

Nesse caso, dir-se-ia que o respeito ao contraditório estaria preservado, uma vez que se emprestaria ao sócio, ao qual foi estendida a obrigação de pagar o crédito tributário (por força do instituto da responsabilidade tributária), o mesmo tratamento previsto ao devedor originário e sujeito passivo da execução fiscal.

Aqui convém divisar o tratamento díspar que a jurisprudência dá ao sócio responsável tributário conforme o seu nome figure ou não na certidão de dívida ativa que aparelha a execução fiscal. Entende o Superior Tribunal de Justiça que figurando o nome do sócio na certidão de dívida ativa, a sua colocação no polo passivo da execução se daria sem maior dificuldade, pois, ante a presunção de veracidade que se confere ao título executivo,

\footnotetext{
${ }^{31}$ (...) 1. Os embargos declaratórios são cabíveis para a modificação do julgado que se apresenta omisso, contraditório ou obscuro. 2. Consoante pacificado na Seção de Direito Público, o redirecionamento da execução contra o sócio deve ocorrer no prazo de cinco anos da citação da pessoa jurídica, devendo a situação harmonizar-se com as hipóteses previstas no art. 174 do CTN, de modo a não tornar imprescritivel a dívida fiscal. 3. No caso dos autos, o sócio somente foi citado quando já decorrido mais de 10 (dez) anos da citação da empresa, lapso de tempo mais que suficiente à consumação da prescrição intercorrente. Embargos de declaração acolhidos, com efeitos modificativos, para declarar a ocorrência prescrição intercorrente. (g.n.) (EDcl no REsp 969.382/PR, Rel. Min. Humberto Martins, Segunda Turma, j. em 02.09.2008, DJe 19/09/2008).
} 
Revista Eletrônica de Direito Processual - REDP.

Rio de Janeiro. Ano 10. Volume 17. Número 1. Janeiro a Junho de 2016

Periódico Semestral da Pós-Graduação Stricto Sensu em Direito Processual da UERJ

Patrono: José Carlos Barbosa Moreira. ISSN 1982-7636. pp. 92-111 http://www.e-publicacoes.uerj.br/index.php/redp/index

o ônus da prova se inverteria contra o sócio, que passa a ter que provar a ausência dos requisitos da responsabilidade tributária ${ }^{32-33}$.

Nos casos em que isso não se verifica, isto é, nos caso em que o nome do sócio não figure como corresponsável tributário na certidão de dívida ativa, o ônus da prova quanto aos requisitos delineadores da responsabilidade tributária seria do fisco e não do sócio, militando em favor deste a presunção de não corresponsabilidade.

Nessa perspectiva, é de ser encontrar uma linha de harmonização entre estas diferentes posições do sócio: (i) encontrar-se com a responsabilidade pessoal tributária já reconhecida e, com isso, já ter o nome como corresponsável na certidão de dívida ativa; ou (ii) não ter tido reconhecida previamente (na fase do processo administrativo tributário em que se houve a constituição do crédito) a sua corresponsabilidade pelo adimplemento do crédito tributário.

No primeiro caso (i), por ser a posição do sócio frente à execução fiscal análoga ao da pessoa jurídica contribuinte, não se vislumbra maior dificuldade em admiti-lo no polo passivo da execução fiscal, ainda que em momento subsequente ao ajuizamento desta, desde que não operada a prescrição do crédito tributário. Considerando que ambos, nos termos da legislação tributária, são igualmente sujeitos passivos do crédito tributário, encontrando-se

\footnotetext{
32 PROCESSUAL CIVIL E TRIBUTÁRIO - AGRAVO REGIMENTAL EM AGRAVO EM RECURSO ESPECIAL - EXECUÇÃO FISCAL - VIOLAÇÃO DO ART. 535, II, DO CPC - NÃO CONHECIMENTO REDIRECIONAMENTO - PRESUNÇÃO DE LEGITIMIDADE DO TÍTULO EXECUTIVO EM QUE CONSTA O NOME DO DEVEDOR - MATÉRIA DECIDIDA DE ACORDO COM A SISTEMÁTICA DO ART. 543-C DO CPC - DESCABIMENTO DO AGRAVO REGIMENTAL - APLICAÇÃO DA MULTA PREVISTA NO ART. 557, § $2^{\circ}$, DO CPC. 1. A violação do art. 535, II, do CPC, para ser conhecida, pressupõe tenha o recorrente oposto embargos de declaração na origem, a fim de suscitar pronunciamento do tribunal a quo com relação a matéria sobre a qual tenha havido omissão. 2. A Primeira Seção do STJ, ao apreciar o REsp 1.104.900/ES, sob o rito dos recursos repetitivos, firmou o entendimento de que a presunção de legitimidade do título executivo extrajudicial viabiliza o redirecionamento da Execução Fiscal contra sócio- gerente cujo nome estiver incluido na $C D A$. 3. Verifica-se que o agravo ataca decisão que se fundamentou em precedente julgado pelo art. 543-C, razão que justifica a aplicação da multa prevista no art. 557 , § $2^{\circ}$, do CPC no valor de $10 \%$ sobre o valor atualizado da causa. 4. Agravo regimental não provido. (g.n.) (AgRg no AREsp 317.050/MS, Rel. Min. Eliana Calmon, Segunda Turma, j. em 12.11.2013, DJe 20/11/2013).

${ }^{33}$ PROCESSUAL CIVIL E TRIBUTÁRIO. EXECUÇÃO FISCAL. RESPONSABILIDADE DE SÓCIO INDICADO NA CDA. PRESUNÇÃO DE LEGITIMIDADE. MATÉRIA DECIDIDA NO RITO DO ART. 543-C DO CPC. 1. Não há previsão legal que obrigue o relator do Agravo Regimental, no caso de reconsideração, a abrir vista para o agravado se manifestar. Ademais, a possível nulidade da decisão monocrática por violação do contraditório e da ampla defesa fica superada com a reapreciação do recurso pelo órgão colegiado, na via de Agravo Regimental. Precedentes do STJ. 2. A Primeira Seção do STJ pacificou o entendimento de que a presunção de liquidez e certeza do título executivo faz com que, nos casos em que o nome do sócio-gerente conste da CDA, o ônus da prova seja transferido ao gestor da sociedade. 3. Agravo Regimental não provido. (g.n.) (AgRg no AgRg no Ag 1217410/RJ, Rel. Min. Herman Benjamin, Segunda Turma, j. em 14.12.2010, DJe 04/02/2011).
} 
Revista Eletrônica de Direito Processual - REDP.

Rio de Janeiro. Ano 10. Volume 17. Número 1. Janeiro a Junho de 2016

Periódico Semestral da Pós-Graduação Stricto Sensu em Direito Processual da UERJ

Patrono: José Carlos Barbosa Moreira. ISSN 1982-7636. pp. 92-111

http://www.e-publicacoes.uerj.br/index.php/redp/index

o sócio com a sua responsabilidade tributária já declarada, é admissível a fórmula paritária de tratamento pela legislação processual, bastando, portanto, em relação ao sócio responsável que figure na certidão de dívida ativa, que seja incluído no polo passivo da execução fiscal, não como terceiro, mas como verdadeira parte passiva, sendo citado nos termos da Lei 6.830/80.

Mesmo nesse caso, por força do devido processo legal e ausência de razões justificadoras para dar ao sócio um tratamento pior que a empresa contribuinte, não se deve admitir a prática de atos de constrição patrimonial antes da citação e do fluxo do prazo para garantia do juízo, o que revela a inconstitucionalidade do entendimento jurisprudencial do Superior Tribunal de Justiça que admite a inclusão do sócio na execução fiscal sem prévia citação, priorizando-se, antes desta, a penhora de bens.

No segundo caso (ii), porém, em que a prova dos requisitos da responsabilidade tributária do sócio é ônus processual do fisco, autor da execução fiscal, a despeito dessa responsabilidade ser distinta ou não do instituto da desconsideração da personalidade jurídica, cabe a aplicação das regras do incidente de desconsideração em análise, na forma prevista no novo Código de Processo Civil.

Ainda que o reconhecimento da responsabilidade tributária ${ }^{34}$ implique a corresponsabilidade do sócio pelo crédito tributário (figurando como sujeito passivo do crédito e não mero terceiro), isso de modo algum obstaculiza o uso do procedimento do incidente de intervenção de terceiro em análise, pois que a dita responsabilidade tributária, ainda que existente, deverá ser declarada, dependendo de regular e válida comprovação.

Sendo necessária a prova dos pressupostos conformadores da responsabilidade tributária do sócio e o reconhecimento desta responsabilidade, não poderá ser ele simplesmente incluído no polo passivo da ação de execução fiscal sem que tal situação seja discutida ou submetida a debate. Fosse assim, e estar-se-ia diante de flagrante violação ao princípio do contraditório, mesmo que em sua versão fraca, aqui compreendida como a garantia de ciência e possibilidade de resposta (participação), pois o reconhecimento da

\footnotetext{
34 “(...) responsabilidade tributária é o instituo de direito tributário que consiste na determinação, por lei, a pessoa não contribuinte de determinado tributo (responsável tributário) que, por se encontrar em situação que lhe enseje a prática ou abstenção de determinados atos úteis à Administração Tributária por impedirem ou minimizarem a evasão e o inadimplemento por parte do contribuinte ou facilitarem a fiscalização, assim o faça, sob pena de responder com seu próprio patrimônio pela satisfação do tributo devido e inadimplido pelo contribuinte.” In: PAULSEN, Leandro. Responsabilidade e Substituição Tributárias. Porto Alegre. Livraria do Advogado Editora, 2012, p. 60.
} 
Revista Eletrônica de Direito Processual - REDP.

Rio de Janeiro. Ano 10. Volume 17. Número 1. Janeiro a Junho de 2016

Periódico Semestral da Pós-Graduação Stricto Sensu em Direito Processual da UERJ

Patrono: José Carlos Barbosa Moreira. ISSN 1982-7636. pp. 92-111 http://www.e-publicacoes.uerj.br/index.php/redp/index

responsabilidade tributária, neste caso, se daria sem a prévia comunicação do sujeito de direito afetado (o que não é admitido sequer no processo administrativo tributário) ${ }^{35}$.

E não se diga que, frente a essa realidade, tudo se resolveria mediante o diferimento do contraditório, pois esta técnica processual, como alhures se disse, por compreender uma mitigação do direito ao contraditório, está submetida à reserva legislativa, não havendo previsão legal para tanto. Além disso, inexistiriam razões jurídicas relevantes para, neste cenário, equiparar-se o sócio ao devedor originário (e com isso arrastá-lo diretamente para o polo passivo da execução fiscal), pela simples razão de a responsabilidade tributária daquele depender de prova e declaração, ou seja, estar condicionada à cláusula do devido processo legal ${ }^{36}$.

Equiparar o sócio com responsabilidade tributária já reconhecida e declarada no âmbito administrativo fiscal (e que, por isso, tem o nome como corresponsável na certidão de dívida ativa) com aquele que ainda não a teve também significa arrematada violação ao princípio da isonomia, pois as posições jurídicas de um e outro são claramente distintas ${ }^{37}$.

Reconhecida judicialmente, via incidente de desconsideração da personalidade jurídica, a responsabilidade tributária do sócio, este não será tratado como mero terceiro, mas como verdadeira parte passiva, pois, consoante já se afirmou, o instituto do redirecionamento da execução fiscal decorre do reconhecimento da própria condição de sujeito passivo do crédito tributário, na qualidade de responsável pessoal, de modo que o sócio, neste caso, também é devedor principal e, por isso, responde pela dívida com o seu patrimônio, diferentemente da figura do sócio cujo patrimônio foi alcançado ante o reconhecimento de alguma causa motivadora da desconsideração da personalidade jurídica,

\footnotetext{
35 “A relação processual é uma relação jurídica, submetida a uma série de princípios, em sua maioria constitucionais, que estabelecem diretrizes a serem seguidas pelas partes e especialmente pelo julgador no exercício da função de aplicar o direito na resolução de conflitos, quer na esfera judicial, no exercício da atividade jurisdicional propriamente dita; quer na esfera administrativa, na qual a resolução de conflitos por meio de um processo contraditório se submete aos praticamente mesmos princípios do processo judicial. E mesmo os meros procedimentos administrativos não contenciosos, nos quais é exercida a atividade administrativa própria, ou típica - tais como o procedimento de fiscalização, de reconhecimento de imunidades ou isenções etc. -, submetem-se a princípios inerentes ao Direito como um todo, e especialmente ao Direito Público.” In: MACHADO SEGUNDO, Hugo de Brito. Processo Tributário. $5^{\text {a }}$ ed. São Paulo. Atlas, 2010 , p. 16).

36 "LV - aos litigantes, em processo judicial ou administrativo, e aos acusados em geral são assegurados o contraditório e ampla defesa, com os meios e recursos a ela inerentes;" (art. $5^{\circ}, \mathrm{CF}$ )

37 Ao sócio com responsabilidade tributária reconhecida e declarada no processo administrativo tributário, presume-se que lhe foi assegurado o contraditório e a ampla defesa; ao sócio cuja responsabilidade tributária dependerá ainda de reconhecimento de declaração, não se lhe outorgou a mínima possibilidade de defesa.
} 
Revista Eletrônica de Direito Processual - REDP.

Rio de Janeiro. Ano 10. Volume 17. Número 1. Janeiro a Junho de 2016

Periódico Semestral da Pós-Graduação Stricto Sensu em Direito Processual da UERJ

Patrono: José Carlos Barbosa Moreira. ISSN 1982-7636. pp. 92-111 http://www.e-publicacoes.uerj.br/index.php/redp/index

a exemplo do art. 50 do Código $\mathrm{Civil}^{38}$, o qual, na linguagem civilista, embora não tenha o débito, se torna responsável ${ }^{39}$, pois passa a responder pela dívida com o seu patrimônio.

Em qualquer caso, contudo, é preciso assegurar-lhe o direito ao contraditório, em toda a sua extensão e dimensão, pois somente assim é que se estará dando concretude ao direito de defesa em sentido amplo, compreendido no âmbito de proteção do devido processo legal, da ampla defesa e do contraditório.

Por conseguinte, o procedimento do incidente de desconsideração da personalidade jurídica terá cabimento mais precisamente naqueles casos em que o nome do sócio pretensamente responsável tributário não figure no título executivo da execução fiscal, tendo em vista que, nesta hipótese, consoante a jurisprudência do Superior Tribunal de Justiça, não há inversão do ônus da prova para o contribuinte em relação à ausência da responsabilidade tributária, cabendo ao fisco-exequente demonstrá-la adequadamente.

Tratando-se de genuína desconsideração da personalidade jurídica em sede tributária, para aqueles que entendem possível a aplicação do instituto ao âmbito físcal independentemente das normas afetas à responsabilidade tributária do sócio, a observância das regras do incidente de desconsideração da personalidade jurídica previsto no novo

\footnotetext{
38 "Art. 50. Em caso de abuso da personalidade jurídica, caracterizado pelo desvio de finalidade, ou pela confusão patrimonial, pode o juiz decidir, a requerimento da parte, ou do Ministério Público quando lhe couber intervir no processo, que os efeitos de certas e determinadas relações de obrigações sejam estendidos aos bens particulares dos administradores ou sócios da pessoa jurídica."

39 , "Inicialmente, o Schuld é o dever legal de cumprir com a obrigação, o dever existente por parte do devedor. Havendo o adimplemento da obrigação surgirá apenas esse conceito. Mas, por outro lado, se a obrigação não é cumprida, surgirá a responsabilidade, o Haftung. Didaticamente, pode-se utilizar a palavra Schuld como sinônima de debitum e Haftung, de obligatio." In: TARTUCE, Flávio. Manual de Direito Civil: volume único. $3^{\text {a }}$ ed. São Paulo. Método, 2013. p. 393.
} 
Revista Eletrônica de Direito Processual - REDP.

Rio de Janeiro. Ano 10. Volume 17. Número 1. Janeiro a Junho de 2016

Periódico Semestral da Pós-Graduação Stricto Sensu em Direito Processual da UERJ

Patrono: José Carlos Barbosa Moreira. ISSN 1982-7636. pp. 92-111

http://www.e-publicacoes.uerj.br/index.php/redp/index

Código de Processo Civil não apresenta qualquer problemática, não se entrevendo sequer a possibilidade de divergência, pois formatado precisamente para regular a hipótese $\mathrm{e}^{40}{ }^{41}$.

VII. NECESSIDADE DE REQUERIMENTO DE MEDIDA CAUTELAR FISCAL OU DE TUTELA DE URGÊNCIA CAUTELAR PARA A PRÉVIA CONSTRIÇÃO DE BENS EM NOME DO SÓCIO

Em nenhum momento se afirmou a impossibilidade de decisão judicial para a constrição de bens do sócio antes da sua manifestação em juízo. Enfatizou-se, isto sim, que atos dessa natureza qualificam-se como medidas excepcionais e que, como tais, necessitam ser devidamente justificadas e fundamentadas.

40 TRIBUTÁRIO. AGRAVO REGIMENTAL NO AGRAVO EM RECURSO ESPECIAL. ISS. ARRENDAMENTO MERCANTIL (LEASING). ILEGITIMIDADE PASSIVA. NÃO VINCULAÇÃO AO FATO GERADOR. AUSÊNCIA DE ABUSO DA PERSONALIDADE OU CONFUSÃO PATRIMONIAL. NÃO INCIDÊNCIA DA SOLIDARIEDADE OU DA DESCONSIDERAÇÃO DA PERSONALIDADE JURÍDICA. ENTENDIMENTO DIVERSO IMPLICARIA EM REEXAME DE PROVAS. AGRAVO REGIMENTAL DO MUNICÍPIO DE GUAÍABA/RS DESPROVIDO. 1. A Corte de origem, com base em fatos e provas, afirmou, expressamente, que, não foi caracterizada a vinculação do embargante ao fato gerador do serviço e não restou configurada hipótese de abuso de personalidade ou confusão patrimonial, de modo a ser aplicada a teoria da desconsideração da personalidade. Neste caso, modificar tal verificação realizada pelo Tribunal de origem não é daquelas que se possa fazer em sede de Recurso Especial, porquanto a sua constatação demandaria rigorosa análise, o que implicaria em revolvimento de provas. 2. Agravo Regimental do MUNICÍPIO DE GUAÍBA/RS a que se nega provimento. (AgRg no AREsp 621.953/RS, Rel. Min. Napoleão Nunes Maia Filho, Primeira Turma, j. em 03.11.2015, DJe 16.11.2015).

${ }^{41}$ PROCESSO CIVIL. AÇÃO DE EXECUÇÃO. FGTS. REDIRECIONAMENTO. INAPLICABILIDADE DO ART. 135 DO CTN. DESCONSIDERAÇÃO DA PERSONALIDADE JURÍDICA. ART. 50 DO CÓDIGO CIVIL. INOCORRÊNCIA. ENTENDIMENTO ORIGINÁRIO FIXADO COM BASE NO CONTEXTO FÁTICO DOS AUTOS. INCIDÊNCIA DA SÚMULA 7/STJ. 1. É assente nesta Corte o entendimento segundo o qual as disposições do art. 135 do CTN não podem ser aplicadas às execuções referentes a FGTS, pois tal contribuição não tem natureza tributária. Incidência da Súmula n. 353/STJ. 2. Indício de dissolução irregular da sociedade, não é, por si só, apto a ensejar a responsabilidade pessoal dos sócios, já que se depreende pela interpretação do art. 50 do CC que sua aplicação depende da verificação de que a personalidade jurídica esteja sendo utilizada com abuso de direito ou fraude nos negócios e atos jurídicos. 3. A teor do constante do art. 50 do Código Civil, é admitida a desconsideração da personalidade jurídica em situações excepcionais, devendo as instâncias ordinárias, observando os fatos ocorridos, concluir, fundamentadamente, pela ocorrência do desvio de sua finalidade ou confusão patrimonial desta com a de seus sócios, requisitos objetivos sem os quais a medida torna-se incabível. 4. O Tribunal de origem concluiu, a partir da análise das provas constantes dos autos, pela inexistência dos requisitos constantes do dispositivo legal, art. 50 do CC, quais sejam: a) abuso da personalidade jurídica, caracterizado pelo desvio de finalidade; b) confusão patrimonial, aptos a ensejar o redirecionamento do pleito executivo. Conclusão contrária demandaria a incursão no contexto fático probatório dos autos, impossível a esta Corte ante o óbice da Súmula 7/STJ. Agravo regimental improvido. (AgRg no REsp 1378736/SC, Rel. Min. Humberto Martins, Segunda Turma, j. em 22.04.2014, DJe 05.05.2014) 
Revista Eletrônica de Direito Processual - REDP.

Rio de Janeiro. Ano 10. Volume 17. Número 1. Janeiro a Junho de 2016

Periódico Semestral da Pós-Graduação Stricto Sensu em Direito Processual da UERJ

Patrono: José Carlos Barbosa Moreira. ISSN 1982-7636. pp. 92-111 http://www.e-publicacoes.uerj.br/index.php/redp/index

Nesse sentido, a incursão na esfera patrimonial do sócio somente será possível quando presentes hipóteses autorizadoras do manejo das ações cautelares fiscais (Lei 8.397/92) ou da tutela de urgência de natureza cautelar (art. 300 e seguintes do CPC).

Tais vias procedimentais expressam o poder de conformação do legislador em tema de sopesamento abstrato dos direitos fundamentais.

É cediço que os direitos fundamentais não são absolutos. O juízo de ponderação, porém, é em primeiro lugar exercido pelo legislador, no atuar do seu poder de conformação dos preceitos da Constituição.

Havendo a intermediação legislativa, o parâmetro adotado pelo legislador é o que deve ser seguido, possuindo força obrigatória em razão do princípio do Estado de Direito e da legalidade. Somente quando a norma se revela insuficiente ou desproporcional no caso concreto é que poderá o Poder Judiciário superar o conflito de regras e princípios envolvidos, realizando a justiça do caso concreto.

Desse modo, a mitigação do contraditório em relação ao sócio que não integra a relação processual da execução fiscal, qualquer que seja a sua posição de responsabilidade tributária (já declarada ou não), pode ocorrer desde que observadas as diretrizes legais, estas configuradas nos modelos viabilizadores das ações cautelares fiscais (procedimentos não revogados pelo novo $\mathrm{CPC}$ - art. 1.046, $\S 2^{\circ}$ ) e dos procedimentos de tutela de urgência de natureza cautelar, conforme já referido.

\section{CONCLUSÃO}

As lições que fundamentam a pesquisa, colhidas na doutrina e na jurisprudência, permitem concluir na direção da aplicação do procedimento do incidente de desconsideração da personalidade jurídica, previsto no novo Código de Processo Civil, ao âmbito da execução fiscal, servindo o seu regramento de pauta ao redirecionamento do executivo tributário quando o sócio pretensamente responsável não tenha participado da fase administrativa de constituição do crédito tributário e ai reconhecida a sua corresponsabilidade.

A partir do estudo encetado é possível constatar tanto a compatibilidade procedimental do incidente de desconsideração da personalidade jurídica com o procedimento de execução fiscal, como também a relevância de seu regramento para a 
Revista Eletrônica de Direito Processual - REDP.

Rio de Janeiro. Ano 10. Volume 17. Número 1. Janeiro a Junho de 2016

Periódico Semestral da Pós-Graduação Stricto Sensu em Direito Processual da UERJ

Patrono: José Carlos Barbosa Moreira. ISSN 1982-7636. pp. 92-111 http://www.e-publicacoes.uerj.br/index.php/redp/index

efetiva realização dos direitos fundamentais que tangem o devido processo legal, especialmente o princípio do contraditório.

Segundo o enfoque que direcionou o estudo, denota-se que a marca característica do incidente examinado é a inclinação para a realização do contraditório de envergadura substancial e que visa à realização do contraditório efetivo, franqueando o poder de influenciar a tomada de decisão pelo órgão jurisdicional.

Assim, a tomada de empréstimo do incidente em testilha ao processo judicial tributário corrige uma grave falha impeditiva da realização do contraditório efetivo. Isso porque, a despeito do contraditório poder ser exercido posteriormente à decisão do órgão judicial que enfrenta os requisitos legais autorizadores do redirecionamento da execução fiscal (contraditório diferido), é inegável que nesse momento o sócio estará em posição de evidente desvantagem perante a contraparte credora (o fisco). O juízo de verossimilhança ou de probabilidade acerca da responsabilidade tributária importa inequívoco prejulgamento do contexto fático-jurídico pelo órgão jurisdicional, minimizando drasticamente as possibilidades de influência sobre o convencimento do magistrado. Além disso, é quase certo que esse contraditório posterior será exercido sob condições adversas, isto é, frente a invasão ou afetação da esfera de direitos patrimoniais do sócio, decorrentes dos atos de constrição patrimonial inerentes ao processo de execução fiscal, cuja finalidade precípua é a prática de atos materiais que levem à satisfação do crédito, isto é, à realização da pretensão inadimplida.

Com isso tem-se a convicção de que a pesquisa contribui para a compreensão do incidente de desconsideração da personalidade jurídica como um mecanismo de realização do contraditório efetivo no âmbito da execução fiscal, precisamente quando seja necessário redirecioná-la ao sócio cuja responsabilidade tributária se pretenda reconhecer, assegurandose, também nessa seara processual, a maior efetividade dos direitos fundamentais do contribuinte.

\section{REFERÊNCIAS BIBLIOGRÁFICAS:}

BARROSO, Luís Roberto. Direito Constitucional Contemporâneo: os conceitos fundamentais e a construção do novo modelo. $3^{\mathrm{a}}$ ed. São Paulo. Saraiva, 2011. 
Revista Eletrônica de Direito Processual - REDP.

Rio de Janeiro. Ano 10. Volume 17. Número 1. Janeiro a Junho de 2016

Periódico Semestral da Pós-Graduação Stricto Sensu em Direito Processual da UERJ

Patrono: José Carlos Barbosa Moreira. ISSN 1982-7636. pp. 92-111 http://www.e-publicacoes.uerj.br/index.php/redp/index

BRASIL. Lei 5.172, de 25 de outubro de 1.966. Disponível em http://www.planalto.gov.br/ccivil_03/leis/L5172.htm. Acesso em 03 de abril de 2016.

BRASIL. Superior Tribunal de Justiça, AgRg no REsp 1459784/MS, Rel. Min. Marco Aurélio Bellizze, Terceira Turma, julgado em 04/08/2015, DJe 14/08/2015. Disponível em http://www.stj.jus.br/SCON/jurisprudencia/toc.jsp?livre=desnecessidade+de+cita $\% \mathrm{E} 7 \% \mathrm{E} 3$ $\mathrm{o}+\mathrm{e}+\mathrm{s} \% \mathrm{~F} 3 \operatorname{cios}+$ atingidos $\& \& \mathrm{~b}=\mathrm{ACOR} \&$ thesaurus $=$ JURIDICO. Acesso em 04 de abril de 2016.

CARNEIRO, Wálber Araujo. Hermenêutica Jurídica Heterorreflexiva: uma teoria dialógica do direito. Porto Alegre. Livraria do Advogado Editora, 2011.

DIDIER JR., Fredie. Curso de Direito Processual Civil: introdução ao direito processual civil, parte geral e processo de conhecimento. $17^{\mathrm{a}}$ ed. Salvador. Jus Podivm, 2015.

MACHADO SEGUNDO, Hugo de Brito. Processo Tributário. $5^{\mathrm{a}}$ ed. São Paulo. Atlas, 2010. MENDES, Gilmar Ferreira. Direitos Fundamentais e Controle de Constitucionalidade: estudos de direito constitucional. $4^{\mathrm{a}}$ ed. São Paulo. Saraiva, 2012.

OLIVEIRA, Carlos Alberto Alvaro de. Comentário ao art. $5^{\circ}$, LV. In: CANOTILHO, J.J. Gomes; MENDES, Gilmar F.; SARLET, Ingo W.; STRECK, Lenio L. (Coords.). Comentários à Constituição do Brasil. $1^{\mathrm{a}}$ ed. São Paulo. Saraiva, 2014.

PAULSEN, Leandro. Responsabilidade e Substituição Tributárias. Porto Alegre. Livraria do Advogado Editora, 2012.

SARLET, Ingo Wolfgang; MARINONI, Luiz Guilherme; MITIDIERO, Daniel. Curso de Direito Constitucional. São Paulo. Revista dos Tribunais, 2012.

SILVA, Alexandre Alberto Teodoro da. A Desconsideração da Personalidade Jurídica no Direito Tributário. São Paulo. Quartier Latin, 2007.

SOUZA NETO, Cláudio Pereira de; SARMENTO, Daniel. Direito Constitucional: teoria, história e métodos de trabalho. Belo Horizonte. Fórum, 2012.

STRECK, Lenio Luiz. Jurisdição Constitucional e Decisão Jurídica. $3^{\mathrm{a}}$ ed. Reformulada da obra Jurisdição Constitucional e Hermenêutica. São Paulo. Revista dos Tribunais, 2013.

TARTUCE, Flávio. Manual de Direito Civil: volume único. $3^{\text {a }}$ ed. São Paulo. Método, 2013. 